\title{
Oil and food prices in Malaysia: a nonlinear ARDL analysis
}

Mansor H Ibrahim

Correspondence:

mansorhi@hotmail.com

International Center for Education

in Islamic Finance (INCEIF), Lorong Universiti A, 59100 Kuala Lumpur,

Malaysia

\section{Springer}

\begin{abstract}
The present paper analyses the relations between food and oil prices for Malaysia using a nonlinear autoregressive distributed lags (NARDL) model. The bounds test of the NARDL specification suggests the presence of cointegration among the variables, which include the food price, oil price and real GDP. The estimated NARDL model affirms the presence of asymmetries in the food price behavior. Namely, in the long run, we find a significant relation between oil price increases and food price. Meanwhile, the long run relation between oil price reduction and the food price is absent. Furthermore, in the short run, only changes in the positive oil price exert significant influences on the food price inflation. With the absence of significant influence of oil price reduction on the food price both in the long run and in the short run, the role of market power in shaping the behavior of Malaysia's food price is likely to be significant.
\end{abstract}

Keywords: Food price behavior; Oil price; Asymmetry; ARDL; Malaysia

JEL classification: C22; E31

\section{Introduction}

The episodes of rising food prices witnessed in recent years, especially during 2007-2008 and 2010-2011, have stimulated extensive popular and academic discussions and placed governments on alert as to their socio-economic implications ${ }^{\mathrm{a}}$. With the need to carve or suggest policy prescriptions to contain food price escalation, numerous studies have been undertaken to identify determinants of food price variations. It is not surprising that, with concurrent upswings of crude oil price during the same years, the oil price has been examined as a potential explanation. A conventional wisdom tells us that, by affecting energy-intensive inputs such as fertilizers and fuel and influencing transportation costs, the oil price changes directly affect food production costs and subsequently food prices. In addition, given the increasing costs of global food production, food import bills would surge during times of rising oil price for food-importing countries and accordingly further exert an upward pressure on domestic prices of food items. Finally, the food versus fuel debate also links food price to oil price through the increase in food demand for the production of biofuels.

While the positive link between oil and food prices is well founded, existing empirical evidence is far from being uniform. Such studies as Zhang and Reed (2008), Zhang et al. (2010), Lambert and Miljkovic (2010), Nazlioglu and Soytas (2011), and more recently Reboredo (2012) have suggested the neutrality or, at best, only marginal 
reaction of various agricultural or food prices to oil price fluctuations. Evaluating the agricultural price (i.e. corn, soy meal and pork) uptrend in China from January 2000 to October 2007, Zhang and Reed (2008) side-line the oil price as a major underlying factor. By the same token, farm wages and manufacturing wages rather than fuel prices are noted to account for variations in the US food prices from 1970 to 2009 by Lambert and Miljkovic (2010). Further evidence is provided by Nazlioglu and Soytas (2011) for the case of Turkey. More specifically, examining the relations between oil price, lira-dollar exchange rate and individual agricultural prices (wheat, maize, cotton, soybeans and sunflower) using monthly data from January 1994 to March 2010, they provide evidence for the neutrality of these prices to oil price changes. This finding reaffirms earlier results for the global commodity prices by Zhang et al. (2010), who document the absence of long run relations and short run interactions between corn, rice, soybeans, sugar and wheat prices and oil price, and it is in line with the recent finding by Reboredo (2012), who notes that the food price spikes experienced in recent years are not caused by drastic increases in oil price. By contrast, Baffes (2007), Harri et al. (2009), Chen et al. (2010), and most recently Baffes and Dennis (2013) all provide evidence indicating significant contribution of oil price to agricultural prices ${ }^{\mathrm{b}}$.

These contrasting findings have continued to excite intense debate and paved ways for further research. Obviously, proper understanding the relations between domestic food prices and oil price for a country is most directly relevant for welfare assessment. However, for proper policy prescriptions to suppress any emerging food price crisis, any analysis of the oil price pass-through to domestic food prices must be cognizant at least indirectly of various underlying domestic factors such as market structure, public regulations, and cost structures. Recognition of these factors may hint on appropriate modelling strategies. More specifically, the presence of market power has normally been viewed to account for asymmetric price behavior with the adjustment to be quicker in the upward direction (Meyer and Cramon-Taubadel, 2004). Adding to this, we may also note the role of public policy schemes such as price floor and price ceiling in influencing asymmetric price behavior since they place the limit to which the price can adjust. Finally, the interplay between firms' cost structures and market power may account for both long run and short run asymmetries in the price movements, as explained by Karantininis et al. (2011a, b).

In this paper, we take part in this stream of research by examining the explanatory role of oil price in food price development from Malaysia's experience and perspectives. Malaysia is a fast-growing Asian economy underpinned by its structural transformation from a commodity-based economy to an industrial-based economy. The transformation has seen Malaysia to be increasingly reliant on food imports for its consumption. Being heavily dependent on food imports, Malaysia is arguably more exposed to oil and global food crises. In the year of escalating food and commodity prices in 2008, Malaysia's food import bills went up by more than 19\%, far exceeding the annual average increase in the import bills of $8.5 \%$ from 2001 to $2010^{\mathrm{c}}$. Accordingly, as regards to food security, Malaysia is likely to be at stake in the face of rising oil price. Further, in Malaysia, Yeong-Sheng (2008) computes the food budget across income quartiles using the Household Expenditure Survey 2004/2005 to be 33.03\%, 25.92\%, 21.2\% and 14.63\% for respectively Quartile 1, Quartile 2, Quartile 3, and Quartile 4. This means that the rising food prices will affect households at lower income quartiles more than those at the 
upper income levels. In light of recent energy market developments, proper assessment of the food price dynamics and its relations to oil price is urgently needed and hence the present analysis.

We adopt an alternative econometric framework, namely the nonlinear autoregressive distributed lags (NARDL) model recently advanced by Shin et al. (2011). We content that, in light of the forgoing discussion, the framework is most appropriate since it allows potential long-run and short-run asymmetries in the food price - oil price relations and hence indirectly hints on the importance of market power and policies in the food price dynamics. The rest of the paper is structured as follows. As a precursor to our analysis, the next section provides some background information and mentions some related studies on Malaysia. Then, Section 3 outlines the empirical approach. Data and results are discussed in Section 4. Finally, Section 5 concludes with the main findings and some concluding remarks.

\section{Background}

Malaysia's economic performance since independence in 1957 has been commendable, as manifested by its growth and inflation performance ${ }^{d}$. Over the span of more than 40 years from 1971 to 2012, Malaysia has experienced an annual average growth rate of $6.1 \%$. The high growth performance of Malaysia, however, has also been marked by several setbacks, notably by the recessions of 1985 and 1998. After recording the average growth rate of $7.4 \%$ per year from 1971 to 1984, the real GDP contracted by slightly more than 1\% in 1985. During 1987-2006, Malaysia witnessed miraculous growth performance registering the average growth rate of more than $8.5 \%$ per year. The onedecade long of high growth performance, however, was interrupted by the eruption of the Asian financial crisis in mid-1997. In 1998, Malaysia's real GDP contracted by more than $7 \%$ after recording the growth rate of more than 7\% in 1997. Malaysia resumed its positive growth pattern again after the crisis. Despite recurring political and financial uncertainties since the Asian crisis with the latest global financial crisis being the notable example, Malaysia managed to record the average GDP growth rate of 5.0\% during 1999-2012. In parallel, Malaysia has also recorded low inflation rate especially since 1985. Prior to 1985, i.e. 1971-1984, the average yearly inflation rate in Malaysia is $6.0 \%$. Meanwhile, the corresponding figure for the period 1986-2012 is $2.6 \%$.

These favourable indicators notwithstanding, the recent sharp swings in the oil price have generated a great deal of concern especially on the effects of oil price or the global food price on the domestic food price. To place this concern into perspectives, Figure 1 graphs the consumer price inflation as well as food price inflation from 1971-2012. As may be observed from the figure, despite low inflationary environment, Malaysia experienced several spikes of inflation, most notably in 1974 and 1981 where inflation peaked respectively at $16 \%$ and $9 \%$. These two high inflation episodes are normally associated with the oil shocks of 1973 and 1979. Accordingly, with the recent sharp swings in the oil price, the inflationary effect of oil price has again taken a central stage in popular and policy discussion. Adding to this, the food price has exhibited higher volatility over the years with its upswing to be relatively steeper despite various policy mechanisms such as price controls and subsidies in place. This means that the welfare of especially lower groups of income is more likely to be at stake given their higher budget share on food items (Yeong-Sheng, 2008), an issue that requires immediate treatment. 


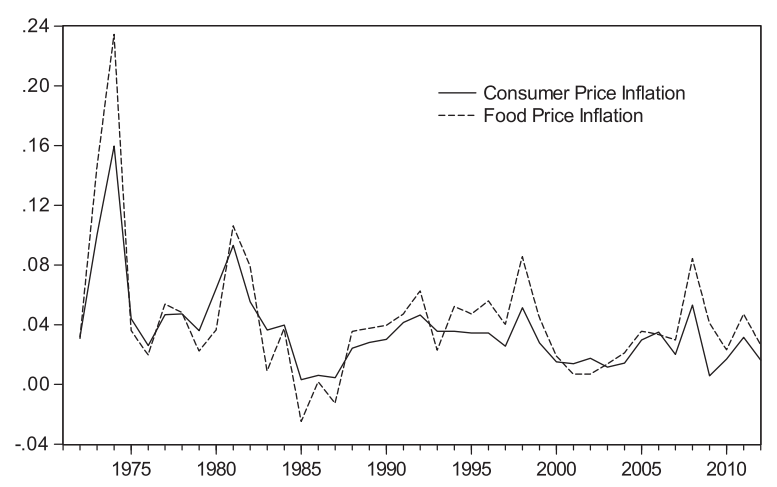

Figure 1 Consumer price inflation and food price inflation in Malaysia. Data source: Bank Negara Malaysia's Monthly Statistical Bulletin.

In addition, the growth performance of Malaysia has been underlined by its structural transformation from a commodity-based economy to an industrial-based economy. Over the years, Malaysia has become more and more dependent on food imports for the purpose of consumption. In Figure 2, we graph the nominal food imports in million ringgit (left axis) and oil price in ringgit (right axis). The nominal food imports have steadily increased over the years in parallel with the increase in real GDP. However, despite lower GDP growth in later years, the food import bills have been escalating especially since 2003, the period when the oil price witnessed a sharp increase. Hence, with the rising food import bills, the concern over food price inflation is well placed.

For Malaysia, empirical studies on inflation virtually centre on the aggregate price inflation and most of these studies predominantly look at the role played by money supply. See Ibrahim (2010), Tang (2010) and references therein. Recently, in the wake of the oil price hikes, several studies have emerged and evaluated the influences of oil price to domestic inflation. These include Cunado and de Gracia (2005), Jongwanich and Park (2009, 2011), and Ibrahim and Said (2012). Among these studies, only Ibrahim and Said (2012) consider the implications of oil price on various disaggregated consumer prices including the food price.

Cunado and de Gracia (2005) analyse the real and inflationary effects of oil price shocks for six Asian countries including Malaysia within the Granger causality framework. In the analysis, various non-linear transformations of oil price are employed.

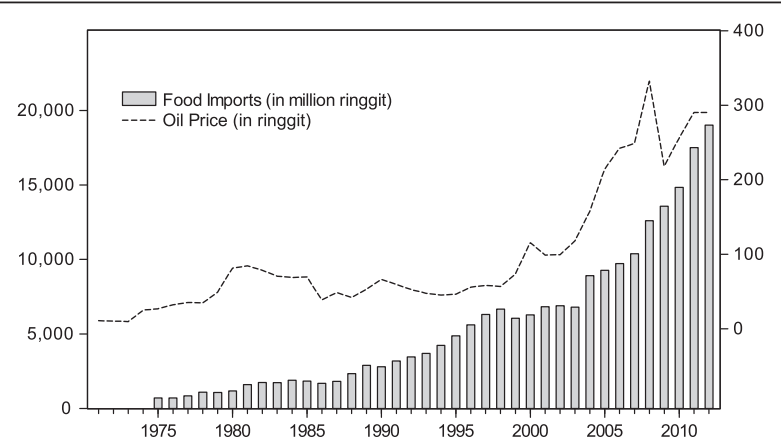

Figure 2 Food imports and oil price. Data source: Food Imports - Bank Negara Malaysia's Monthly Statistical Bulletin; Oil Price - the US Environmental Information Administration. 
They find evidence that oil price shocks anticipate future variations in output growth and inflation especially when the oil price is expressed in local currencies. For the case of Malaysia, when the US dollar oil price is used, none of the oil price measures is found to Granger cause inflation. Using the oil price in ringgit, they also document the lack of Granger causality that runs from the oil price changes to inflation. However, the positive changes in oil price as well as the net oil price increase over 12 quarters tend to anticipate future variations in inflation. It should be noted that they do not compute the pass-through parameter and with the use of variables in first difference, the documented relations are short run in nature.

Contrasting these findings, Jongwanich and Park (2009) marginalize the role of oil and food price shocks in the inflation behavior of nine Asian countries including Malaysia. Aiming at evaluating the relative importance of various sources of inflation, they adopt a vector autoregressive (VAR) framework. According to them, the Asia's inflation is domestically driven. The external price shocks such as oil and food price shocks exert only minimal influences on the Asia's inflation performance. In their subsequent analysis, Jongwanich and Park (2011) estimate the pass-through coefficients of oil and food price shocks of these nine countries and conclude that the pass-through has been limited. In the case of Malaysia, the pass-through coefficient of oil price to producer prices is estimated to be roughly 0.14 while the pass-through to the consumer prices to be 0.025 . They attribute the results to such government policy measures as subsidies and price controls.

More recently, Ibrahim and Said (2012) assess the oil price pass-through to various disaggregated consumer prices including the food price using a dynamic error-correction modelling. They also examine the asymmetric effects of positive and negative oil price changes in the analysis. For the consumer prices, the estimated long run oil price pass-through is 0.027 , which is in close correspondence with that by Jongwanich and Park (2011). The long run pass-through to the food price is noted to be even higher, i.e. 0.056. In addition, they also provide evidence for the significant influences of only positive oil price changes in the short run. Both Cunado and de Gracia (2005) and Ibrahim and Said (2012) hint on the presence of asymmetry in the relations between consumer/food prices and oil price. However, their analyses are restricted to short run asymmetry only. We complement these studies by looking at both long run and short run asymmetries.

\section{Methods}

In the literature, the oil price - food price relations are normally examined by means of the standard time series techniques of cointegration, error-correction modelling and Granger causality. While the techniques enable evaluation of their long-run relations as well as their short-run interactions, they presume symmetric relations between agricultural prices and oil price. Accordingly, they are not adequate to capture potential asymmetries in the food price dynamics arising from among others the presence of market power and public policy schemes, as noted earlier. Recently, Shin et al. (2011) advance a nonlinear ARDL cointegration approach (NARDL) as an asymmetric extension to the well-known ARDL model of Pesaran and Shin (1999) and Pesaran et al. (2001), to capture both long run and short run asymmetries in a variable of interest. We adopt this modelling approach for our purpose ${ }^{\mathrm{e}}$. 
To begin, we specify the following asymmetric long-run equation of food price (Schorderet, 2003 and Shin et al., 2011):

$$
f p_{t}=\alpha_{0}+\alpha_{1} y_{t}+\alpha_{2} o p_{t}^{+}+\alpha_{3} o p_{t}^{-}+e_{t}
$$

where $f p$ is food price, $y$ is real income to capture aggregate demand or business cycle effect, $o p$ is oil price, and $\alpha=\left(\alpha_{0}, \alpha_{1}, \alpha_{2}, \alpha_{3}\right)$ is a cointegrating vector or a vector of long run parameters to be estimated. In (1), $o p_{t}^{+}$and $o p_{t}^{-}$are partial sums of positive and negative changes in $o p_{t}$ :

$$
o p_{t}^{+}=\sum_{i=1}^{t} \Delta o p_{i}^{+}=\sum_{i=1}^{t} \max \left(\Delta o p_{i}, 0\right)
$$

and

$$
o p_{t}^{-}=\sum_{i=1}^{t} \Delta o p_{i}^{-}=\sum_{i=1}^{t} \min \left(\Delta o p_{i}, 0\right)
$$

Based on the above formulation, the long run relation between food price and oil price increases is $\alpha_{2}$, which is expected to be positive. Meanwhile, $\alpha_{3}$ captures the long run relation between food price and oil price reduction. Since they are expected to move in the same direction, $\alpha_{3}$ is expected to be positive. We further posit that the oil price increases will result in higher long run changes in the food price as compared to the food price impact of oil price reduction of the same magnitude, i.e. $\alpha_{2}>\alpha_{3}$. Thus, the long run relation as represented by (1) reflects asymmetric long-run oil price passthrough to the food price.

As shown in Shin et al. (2011), equation (1) can be framed in an ARDL setting along the line of Pesaran and Shin (1999) and Pesaran et al. (2001) as:

$$
\begin{aligned}
\Delta f p_{t}= & \alpha+\beta_{0} f p_{t-1}+\beta_{1} y_{t-1}+\beta_{2} o p_{t-1}^{+}+\beta_{3} o p_{t-1}^{-}+\sum_{i=1}^{p} \phi_{i} \Delta f p_{t-i} \\
& +\sum_{i=0}^{q} \gamma_{i} \Delta y_{t-i}+\sum_{i=0}^{s}\left(\theta_{i}^{+} \Delta o p_{t-i}^{+}+\theta_{i}^{-} \Delta o p_{t-i}^{-}\right)+u_{t}
\end{aligned}
$$

Where all variables are as defined above, $p, q$ and $s$ are lag orders and $\alpha_{2}=-\beta_{2} / \beta_{0}$, $\alpha_{3}=-\beta_{3} / \beta_{0}$, the aforementioned long run impacts of respectively oil price increase and oil price reduction on the food price. $\sum_{i=0}^{s} \theta_{i}^{+}$measures the short-run influences of oil price increases on food price inflation while $\sum_{i=0}^{s} \theta_{i}^{-}$the short run influences of oil price reduction on food price inflation. Hence, in this setting, in addition to the asymmetric long run relation, the asymmetric short-run influences of oil price changes on food price inflation are also captured.

Empirical implementation of the nonlinear ARDL approach entails the following steps. First, while the ARDL approach to cointegration is applicable irrespective of whether the variables are $\mathrm{I}(0)$ or $\mathrm{I}(1)$, it is still necessary to conduct unit root tests such that no $\mathrm{I}(2)$ variable is involved. This is important since the presence of an $\mathrm{I}(2)$ variable renders the computed F-statistics for testing cointegration invalid. To this end, we apply the widelyused ADF and PP unit root tests for establishing the variables' orders of integration. In 
the second step, we estimate equation (4) using the standard OLS estimation method. As in Katrakilidis and Trachanas (2012), we adopt the general-to-specific procedure to arrive at the final specification of the NARDL model by trimming insignificant lags. Third, based on the estimated NARDL, we perform a test for the presence of cointegration among the variables using a bounds testing approach of Pesaran et al. (2001) and Shin et al. (2011). This involves the Wald F test of the null hypothesis, $\beta_{0}=\beta_{1}=\beta_{2}=\beta_{3}=0$. In the final step, with the presence of cointegration, examination of long-run and short-run asymmetries in the relations between oil and food prices is made and inferences are drawn. In this step, we can also derive the asymmetric cumulative dynamic multiplier effects of a one percent change in $o p_{t-1}^{+}$and $o p_{t-1}^{-}$respectively as:

$$
m_{h}^{+}=\sum_{j=0}^{h} \frac{\partial y_{t+j}}{\partial o p_{t-1}^{+}}, \quad m_{h}^{-}=\sum_{j=0}^{h} \frac{\partial y_{t+j}}{\partial o p_{t-1}^{-}}, \quad h=0,1,2 \ldots .
$$

Note that as $\mathrm{h} \rightarrow \infty, m_{h}^{+} \rightarrow \alpha_{2}$ and $m_{h}^{-} \rightarrow \alpha_{3}$.

\section{Results and Discussion}

We employ annual data from 1971 to 2012 in the analysis. The food price index corresponding to the food price component of the consumer price index is used to capture the food price $(f p)$ in Malaysia. The real income is represented by real gross domestic product $(y)$. For the oil price $(o p)$, the West Texas intermediate crude oil price in ringgit, i.e. $o p_{r m}=o p \times r m$, is used, where $r m$ is the ringgit exchange rate vis-à-vis the US dollar. In their analysis of several Asian countries, Cunado and de Gracia (2005) find that the inflationary effect of oil price hikes is more prevalent when the oil price is expressed in domestic currencies. Still, it may be argued that, while the changes in the exchange rate is one of potential channels of the oil price pass-through to domestic prices, the changes in the exchange rate can also be driven by some other factors not related to oil prices. Accordingly, multiplying the oil price with the exchange rate to arrive at the ringgit-denominated oil price may erroneously attribute the pass-through to the oil price when the exchange rate changes are due to non-oil factors. To see this, we plot in Figure 3 the evolution of the ringgit-USD exchange rate together with the oil price in the US dollar. In early years and later years of the sample, oil price increases seem to be accompanied by the ringgit appreciation (or the USD depreciation against

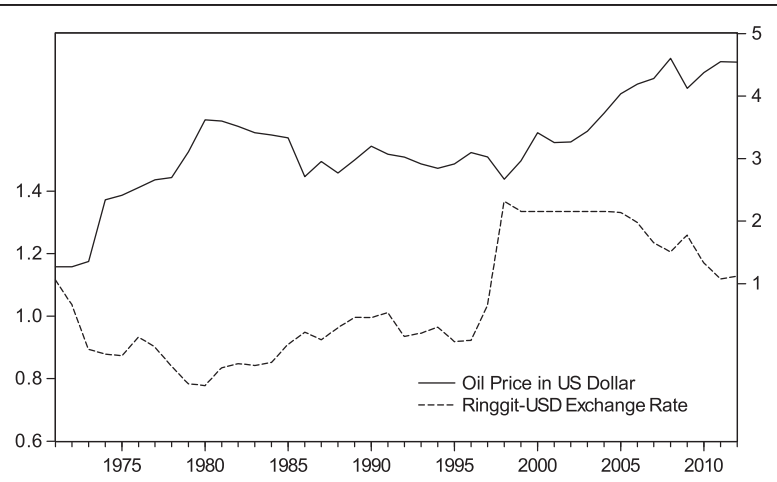

Figure 3 Oil price and Ringgit-USD exchange rate. Data source: Ringgit-USD Exchange Rate - Bank Negara Malaysia's Monthly Statistical Bulletin; Oil Price - the US Environmental Information Administration. 
the ringgit). However, when the ringgit depreciated during 1980s, the oil price was relatively stable. The oil price was also relatively stable during the drastic depreciation of the ringgit in 1997-1998 when Malaysia suffered from the Asian financial crisis. As we are aware, the drastic downfall of the ringgit value stemmed from the crisis. Hence, converting the oil price into the ringgit may erroneously pick up the effect of exchange rate depreciation on food price inflation. As an additional exercise, we also investigate the sensitivity of the results to the employment of the oil price in the US dollar $\left(o p_{\text {usd }}\right)^{\mathrm{f}}$. All variables are expressed in natural logarithm. Except the oil price, the data are sourced from the Monthly Statistical Bulletin of Malaysia's Central Bank (www.bnm. gov.my). The oil price is taken from the US Environmental Information Administration (www.eia.gov).

Given the requirement of the bounds testing procedure that no I(2) variables are involved, we first subject each time series to the ADF and PP unit root tests. The results of these tests are given in Table 1. In the tests, we include both constant and trend terms and employ the SIC for the optimal lag order in the ADF test equation. Both $\mathrm{ADF}$ and PP unit tests are in agreement that real GDP and the two oil price measures are integrated of order 1 . However, for the food price, the ADF test indicates its stationarity in level while the PP test suggests that it becomes stationary after first differencing. Since the tests indicate none of the variables is $\mathrm{I}(2)$, we can proceed to the bounds testing procedure.

Accordingly, we estimate equation (4) and apply the general-to-specific procedure to arrive at the model final specification. The maximum lag order considered is 3 . Table 2 reports the bounds F-statistics and Table 3 present the model estimation results. From the bounds F-statistics, we come to the conclusion that the three variables, i.e. food price, real income and oil price, co-move in the long run. The statistics, 11.90 and 12.48 for respectively equations with oil price in ringgit and oil price in the US dollar, exceed the critical upper bound. With this finding, we are in position to assess the food price dynamics and its relation to real GDP and positive and negative changes in oil price.

Before inferences are drawn, we first judge the adequacy of the dynamic specification on the basis of various diagnostic statistics. These include the Jarque-Bera statistics for error normality (J-B), the LM statistics for autocorrelation up to order 2, and the ARCH statistics for autoregressive conditional heteroskedasticity up to order 2. These are presented at the lower panel of Table 3. In addition, we also graph the CUSUM and CUSUMSQ statistics for testing structural stability of the model in Figure 4. The model with the oil price in ringgit passes all diagnostic tests suggesting error normality,

Table 1 ADF and PP unit root tests

\begin{tabular}{llllll}
\hline & Level & & & & First difference \\
\cline { 2 - 3 } \cline { 5 - 6 } Variable & ADF & PP & & ADF & PP \\
\hline$f p$ & $-4.6516^{* * *}$ & -3.5109 & & $-4.5033^{* * *}$ & $-4.5938^{* * *}$ \\
$y$ & -1.5225 & -1.6961 & & $-5.5803^{* * *}$ & $-5.5819^{* * *}$ \\
$o p_{\text {rm }}$ & -2.1053 & -2.1156 & & $-6.4388^{* * *}$ & $-6.4406^{* * *}$ \\
op & -2.2269 & -2.2275 & & $-6.2351^{* * *}$ & $-6.2351^{* * *}$ \\
\hline
\end{tabular}

Notes: the constant and trend terms are included in the test equations and the SIC is used to select the optimal lag order in the ADF test equation.

${ }^{* * *}$ denote significance at $1 \%$ level. 
Table 2 Bounds test for nonlinear cointegration

\begin{tabular}{lllll}
\hline Oil price specification & F-Statistics & $\mathbf{9 5 \%}$ lower bound & $\mathbf{9 5 \%}$ upper bound & Conclusion \\
\hline op $r m_{\text {rm }}$ & 11.9022 & 4.428 & 6.250 & Cointegration \\
op usd & 12.4833 & & & Cointegration \\
\hline
\end{tabular}

Notes: the critical values are from Narayan (2005), given the small sample size.

absence of autocorrelation and $\mathrm{ARCH}$ effect, and parameter stability. Likewise, the model with the oil price in the US dollar also passes all these tests except the ARCH test. Accordingly, the dynamics of food price inflation is adequately specified.

From the estimated results in Table 3, we compute the cointegrating and long-run equations for both models. These are presented in Table 4. The long run coefficients of real income are positive and significant at $1 \%$ significance level, as should be expected. They suggest that a $1 \%$ increase in real income is related to the increase in the expected food price inflation by roughly $0.50 \%$, holding the oil price constant. Turning to our main theme, we note the asymmetric long run relation between the food price and oil price with the increase in oil price being significantly related to the food price while the reduction in oil price not. In line with many studies, the pass-through of oil price to the food price is not complete. Our estimates suggest that a $10 \%$ increase in the price of oil is associated with the increase in the expected food price in the range of $0.6 \%$ to $0.8 \%$. From the estimates, the use of oil price in ringgit or the oil price in US dollar results in no marked difference in the long run oil price pass through. We believe that a slightly higher magnitude of the oil price pass-through when the oil price is expressed in the ringgit may pick up the effect of ringgit depreciation especially during the episode of the 1997/1998 Asian financial crisis.

Table 3 Nonlinear ARDL estimation results

\begin{tabular}{|c|c|c|c|c|}
\hline \multirow{3}{*}{$\begin{array}{l}\text { Independent } \\
\text { variable }\end{array}$} & \multicolumn{4}{|c|}{ Oil price specification } \\
\hline & \multicolumn{2}{|c|}{ Oil price in Ringgit } & \multicolumn{2}{|c|}{ Oil price in USD } \\
\hline & Coefficient & p-vale & Coefficient & p-value \\
\hline Constant & -1.0406 & 0.0239 & -1.1539 & 0.0100 \\
\hline$p(-1)$ & -0.5592 & 0.0000 & -0.5082 & 0.0000 \\
\hline$y(-1)$ & 0.2690 & 0.0000 & 0.2628 & 0.0000 \\
\hline$o p^{+}(-1)$ & 0.0458 & 0.0041 & 0.0307 & 0.0355 \\
\hline$O P^{-}(-1)$ & 0.0293 & 0.2136 & 0.0216 & 0.2971 \\
\hline$\Delta p(-1)$ & 0.3549 & 0.0397 & 0.2385 & 0.0216 \\
\hline$\Delta o p^{+}$ & --- & --- & 0.0694 & 0.0044 \\
\hline$\Delta o p^{+}(-1)$ & -0.0514 & 0.0397 & --- & --- \\
\hline$R^{2}$ & 0.6798 & & 0.7098 & \\
\hline$J-B$ & 1.4480 & 0.4848 & 1.1050 & 0.5755 \\
\hline $\operatorname{LM}(1)$ & 0.0022 & 0.9622 & 0.1303 & 0.7181 \\
\hline $\operatorname{LM}(2)$ & 0.3534 & 0.8380 & 0.4439 & 0.8010 \\
\hline $\mathrm{ARCH}(1)$ & 0.0040 & 0.9496 & 4.1510 & 0.0416 \\
\hline $\mathrm{ARCH}(2)$ & 0.5286 & 0.7677 & 9.4405 & 0.0089 \\
\hline
\end{tabular}

Notes: J-B is the Jarque-Bera test for error normally, LM(.) is the LM test for error autocorrelation up to the lag order given in the parenthesis, and $\mathrm{ARCH}($.$) is the \mathrm{ARCH}$ test for autoregressive conditional heteroskedasticity up to the lag order given in the parenthesis. 
(a) Model with oil price in domestic currency
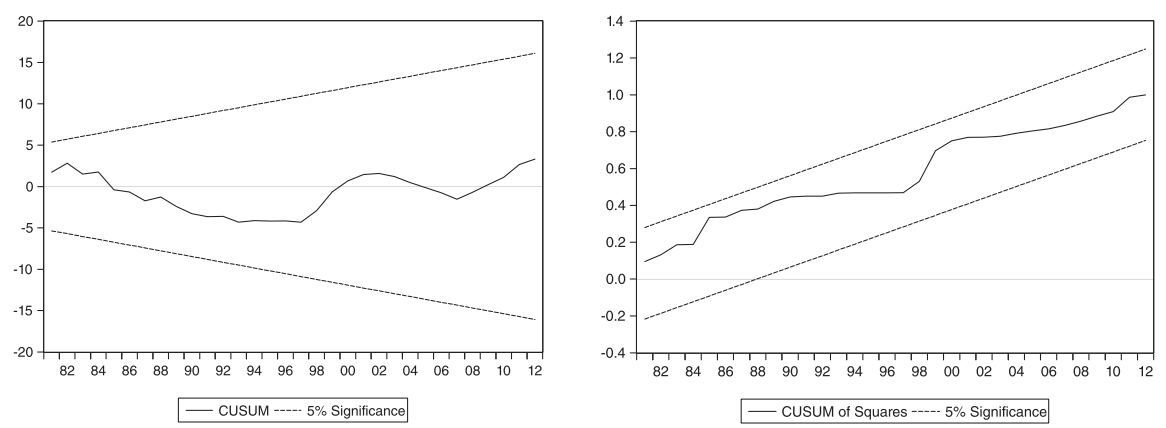

(b) Model with oil price in US dollar
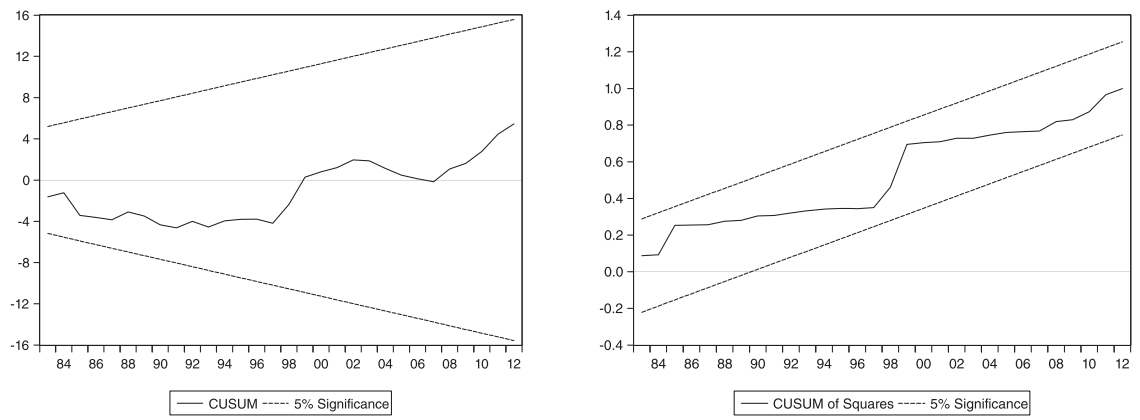

Figure 4 CUSUM and CUSUMSQ.

While the estimates we obtain can be viewed as low, we believe that they are sensible. In the analysis of the global food price, the long run pass-through coefficient is estimated to be 0.18 by Baffes (2007). It should be expected that the effect of oil price should be lower as we go down the supply chain. Hence, it is reasonable to observe lower pass-through to the domestic food price. Moreover, in Malaysia, the prices of several essential food items are controlled and administered by the government. This may have shaped the low oil price - food price relation in the long run, in line with the argument forwarded by Jongwanich and Park (2011).

This low pass-through of oil price increase notwithstanding, it is a cause of concern especially to households at lower income quartiles. Over the past years, the upswings in the oil price have been sharp and, hence, can contribute quite substantially to the food price increase. As an example, in the year of drastic increase in the oil price in ringgit in 2008, the oil price jumped by almost $30 \%$ from the preceding year. On the basis of our estimates, the oil price would account for the increase of roughly $2.4 \%$ in the food

Table 4 Long-run relations

\begin{tabular}{|c|c|c|c|c|}
\hline \multirow[b]{3}{*}{ Variable } & \multicolumn{4}{|c|}{ Oil price specification } \\
\hline & \multicolumn{2}{|c|}{ Oil price in Ringgit } & \multicolumn{2}{|c|}{ Oil price in USD } \\
\hline & Coefficient & p-vale & Coefficient & p-value \\
\hline Constant & -1.8607 & 0.0135 & -2.2707 & 0.0075 \\
\hline$y$ & 0.4810 & 0.0000 & 0.5171 & 0.0000 \\
\hline$o p^{+}$ & 0.0819 & 0.0021 & 0.0605 & 0.0141 \\
\hline$O P^{-}$ & 0.0524 & 0.2053 & 0.0425 & 0.2918 \\
\hline
\end{tabular}


price over the long run. This is high considering the average annual food price inflation in Malaysia of $4.3 \%$. Thus, given higher budget shares of households at quartile 1 (33.03\%) and quartile $2(25.92 \%)$, these groups would be more affected by the oil price increases than those at the upper income levels would. Moreover, as can be further noted from the Table, the long run relation between food price and oil price reduction is insignificant. This finding should be worrying since, while the drastic oil price increase is positively related to food price in the long run, its decline will not be translated into a reduction in the food price. In other words, the high food price will linger around even if the oil price has corrected downward after the initial increase.

As for the short run, our results provide evidence for the presence of asymmetry as well. From Table 3, we may observe only the significance of the positive change in the oil price increase (i.e. $\Delta o p^{+}$). However, the sign of $\Delta o p^{+}$tends to be perverse depending on the model used. In the model with the US dollar-denominated oil price, the change in the oil price increase is contemporaneously and significantly related to the food price inflation. Its coefficient is positive suggesting an impact/immediate increase in the food price inflation by 0.07 percentage point. However, when the oil price in ringgit is used, the once-lagged $\Delta o p^{+}$turns out to be significant and it is negatively signed. One potential explanation is, in the latter, the interplays between the oil price and the ringgit exchange rate may have accounted for the result. We note that, after the de-pegging of the ringgit in July 2005, the ringgit has exhibited an appreciation trend. The period after 2005 has also been marked by the uptrend and sharp swings in the oil price. Apart from these results, we also find some persistence in the food price inflation as reflected by the positive and significant coefficient of once-lagged inflation rate. However, in the short run, real income does not seem to exert any causal influences on the domestic food inflation.

We also compute the short-run and long-run multipliers of oil price increases on the food price. These are given in Figure $5^{\mathrm{g}}$. Corresponding multipliers of oil price reduction are not measured given the insignificant effects of oil price reduction both in the short run and in the long run. Note that, it takes roughly 6 to 7 years for the impact of initial oil price increases to be fully felt; that is, it converges to the long run estimate of 0.0819 after 6 years.

While the sources of asymmetries are not addressed directly in the present paper, the documented patterns of asymmetries tend to hint on the presence of market power

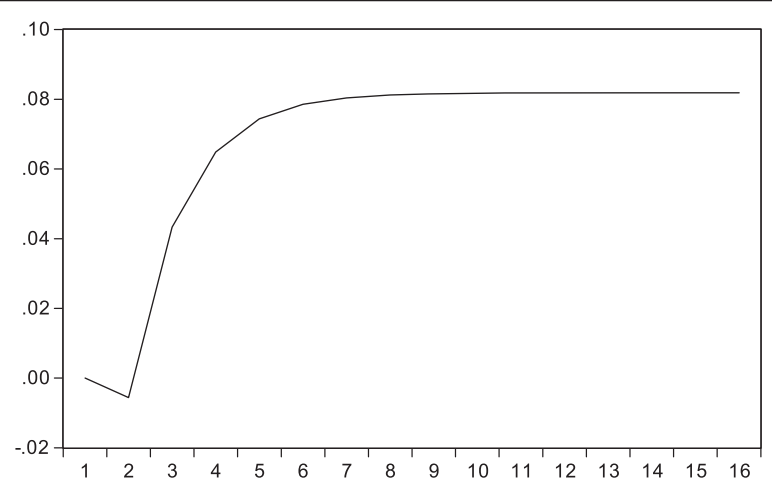

Figure 5 Short-run and long-run multipliers of oil price increases. 
within the food supply chains. As noted by Meyer and Cramon-Taubadel (2004) and discussed in Karantininis et al. (2011a, b), the scale and adjustment costs are the likely sources of short-run asymmetry while the market power the source of long-run asymmetry. Thus, the evidence that the food price is directly related to the increase in the oil price and not to its reduction in the long run provides indication that suppliers may have exercised their market power. Then, the complete absence of the short-run influences of negative oil price changes on the food price further strengthens the conclusion that the market power does play a significant role (Karantininis et al. 2011a, b). On this basis, the recent passage of profiteering and anti-competition acts is a step in the right directions. However, its implementation should not be limited to retailers but should be applied broadly to all suppliers in the supply chain. Moreover, the benefits of such public policy schemes as price controls of essential food items, subsidies and stockpiling are likely to be limited and to work only in the short run unless the issue of market power is properly tackled.

\section{Conclusion}

In this study, we examine the bearings oil price has on the food price index for a net food-importing country, i.e. Malaysia. Recognizing potential roles of market power, cost structures and public policy schemes in shaping asymmetric behavior of the food price, we adopt a nonlinear ARDL model for the analysis to capture both long-run and shortrun asymmetric relations between the food and oil prices. From the analysis, we find evidence for the presence of asymmetries in the long run as well as in the short run. More specifically, in the long run, an oil price increase tends to lead to the increase in the food price while the oil price reduction does not seems to be related to food price. From the estimated cointegrating vectors, we note the degree of pass-through from the oil price increase to the food price to be low and far from complete. Likewise, in the short run, only the changes in the oil price increase are significantly related to the food price inflation. These results are largely similar regardless of whether the oil price in ringgit or the oil price in the US dollar is used.

The low oil price pass-through may be attributed to such public policy schemes as administered prices of essential food items and subsidies as well as adjustment costs. Still, it is a cause of concern especially to those at lower income levels. Over the years, various approaches have been adopted by the government of Malaysia to address rising oil price. These include enhancement of agricultural productivity, betterment of land management, improvement of distribution and marketing chains, effective price administration, stockpiling and subsidies. The recent anti-profiteering and anti-competition acts as regulatory mechanisms to curtail rising domestic prices are also notable.

Our results hint on several aspects of these approaches that need further attention. First, the evidence that only oil price increase and changes in the oil price increase are significantly related to the food price is likely to indicate the presence of market power in the Malaysian food markets. Thus, policy attention should be directed to containing market power and, to be more effective, should cover all suppliers (importers, wholesalers and retailers) in the food supply chain. We believe that the recent profiteering and anti-competition acts are a regulatory step in the right direction. As such, enforcement of these acts must be strengthened. Second, although the persistent budget deficit experienced since 1998 has results in rationalization of oil subsidies on several 
occasions, it must be adopted gradually and together with mechanisms to enhance competition in the domestic food markets and to increase domestically produced food such that there will be minimal impacts on the poor. Finally, the benefits of such existing policy schemes as price controls of essential food items, subsidies and stockpiling are likely to be limited and to work only in the short run unless the issue of market power and agricultural productivity are properly addressed.

\section{Endnotes}

${ }^{a}$ Among the much debated implications of food price increases are malnutrition and poverty (Ivanic et al., 2012, Zheng and Henneberry, 2012, Anriquez et al., 2013, Fujii, 2013, Wood et al. 2012).

${ }^{\mathrm{b}}$ The list of studies on oil and commodity price links is extensive and we mention only few representative studies here. Interested readers may refer to Serra and Zilberman (2013) for a survey.

${ }^{c}$ Food imports refer to nominal imports of primary and processed food and beverages taken from the Monthly Statistical Bulletin published online by Bank Negara Malaysia (www.bnm.gov.my).

${ }^{\mathrm{d}}$ All figures in this section are calculated based on data from the Monthly Statistical Bulletin of Malaysia's Central Bank, i.e. Bank Negara Malaysia.

eAmong studies that have adopted the NARDL method include Katrakilidis and Trachanas (2012) for house price dynamics in Greece, Delatte and Lopez-Villavicencio (2012) for the exchange rate pass-through in four major developed economies, and Verheyen (2013) for the non-linear influence of exchange rates on EMU exports to the US. A notable study related to food price is Karantininis et al. (2011a, b) for the Swedish pork market.

${ }^{\mathrm{f}} \mathrm{We}$ also include the exchange rate in the latter model. However, the exchange rate turns out to be insignificant both in the long run and in the short run while other results remain largely similar. Accordingly, we do not report these results to conserve space.

${ }^{\mathrm{g}}$ The calculation is based on the model with oil price in Ringgit as reported in Table 3.

\section{Competing interests}

The author declares that he has no competing interests.

\section{Acknowledgements}

I would like to thank anonymous referees of the journal for providing constructive comments on the paper. However, any remaining error is my own responsibility.

Received: 1 May 2014 Accepted: 4 December 2014

Published online: 21 January 2015

References

Anriquez G, Daidone S, Mane E (2013) Rising food prices and undernourishment: a cross-country inquiry. Food Policy 38:190-202

Baffes J (2007) Oil spills on other commodities. Resource Policy 32(3):126-34

Baffes J, Dennis A (2013) Long-Term Drivers for Food Prices, The World Bank Policy Research Work Paper No. 6455

Chen S-T, Kua HI, Chen C-C (2010) Modelling the relationship between the oil price and global food prices. Appl Energy 87(7):2517-25

Cunado J, de Gracia FP (2005) Oil prices, economic activity and inflation: evidence from some Asian countries. Q Rev Econ Finance 45(1):65-83

Delatte A-L, Lopez-Villavicencio A (2012) Asymmetric exchange rate pass-through: evidence from major countries. Jacroeconomics 34:833-44

Fujii T (2013) Impact of food inflation on poverty in the Philippines. Food Policy 39:13-27 
Harri A, Nally L, Hudson D (2009) The relationship between oil, exchange rates, and commodity prices. J Agric Appl Econ 41(2):501-10

Ibrahim MH (2010) Money-price relation in Malaysia: has it disappeared or strengthened? Econ Changes Restruct 43(4):303-22

Ibrahim MH, Said R (2012) Disaggregated consumer prices and oil price pass-through: evidence from Malaysia. China Agric Econ Rev 4(4):514-29

Ivanic M, Martin W, Zaman H (2012) Estimating the short-run poverty impacts of the 2010-11 surge in food prices. World Dev 40(11):2302-17

Jongwanich J, Park D (2009) Inflation in developing Asia. J Asian Econoomics 20(5):507-18

Jongwanich J, Park D (2011) Inflation in developing Asia: pass-through from global food and oil price shocks. Asian-Pacific Econ Lit 25(1):79-92

Karantininis K, Katrakylidis K, Persson M (2011a) Price Transmission in the Swedish Pork Chain: Asymmetric Non Linear Ardl. EAAE 2011 Congress, Zurich, Switzerland

Karantininis K, Kostas K, Persson M (2011b) Price transmission in the Swedish pork chain: Asymmetric nonlinear ARDL. Paper presented at the EAAE 2011 Congress: Challenges and Uncertainty, September 2, 2011, Zurich, Switzerland

Katrakilidis C, Trachanas E (2012) What drives housing price dynamics in Greech: new evidence from asymmetric ARDL cointegration. Econ Model 29:1064-9

Lambert DK, Miljkovic D (2010) The sources of variability in US food prices. J Policy Model 32:210-22

Meyer J, Cramon-Taubadel S (2004) Asymmetric price transmission: a survey. J Agric Econ 55(3):581-611

Narayan PK (2005) The saving and investment nexus for China: evidence from cointegration tests. Appl Econ 37(17):1979-90

Nazlioglu S, Soytas U (2011) World oil prices and agricultural commodity prices: evidence from an emerging market. Energy Economics 33(3):488-96

Pesaran MH, Shin Y (1999) An autoregressive distributed lag modelling approach to cointegration analysis. In: Storm S (ed) Econometrics and Economic Theory in the 20th Century: The Ragnar Frisch Centennial Symposium, Chapter 11. Cambridge University Press, Cambridge

Pesaran MH, Shin Y, Smith RJ (2001) Bounds testing approaches to the analysis of level relationship. J Appl Econometrics 16:289-326

Reboredo JC (2012) Do food and oil prices co-move? Energy Policy 49:456-67

Schorderet Y (2003) Asymmetric Cointegration. Working Paper. Department of Economics, University of Geneva

Serra T, Zilberman D (2013) Biofuel-related price transmission literature: a review. Energy Economics 37:141-51

Shin Y, Yu B, Greenwood-Nimmo M (2011) Modelling Asymmetric Cointegration and Dynamic Multiplier in a Nonlinear ARDL Framework, Mimeo

Tang CF (2010) The money-price nexus for Malaysia: new empirical evidence from the time-varying cointegration and causality tests. Glob Econ Rev 39(4):383-403

Verheyen F (2013) Exchange rate nonlinearities in EMU exports to the US. Econ Model 32:66-76

Wood BDK, Nelson CH, Nogueira L (2012) Poverty effects of food price escalation: the importance of substitution effects in Mexican households. Food Policy 37(1):77-85

Yeong-Sheng T (2008) Household Expenditure on Food at Home in Malaysia, MPRA Paper No. 15031

Zhang Q, Reed M (2008) Examining the Impact of the World Crude Oil Price on China's Agricultural Commodity Prices: the Case of Corn, Soybean, and Pork. The Southern Agricultural Economics Association Annual Meeting, Dallas, TX

Zhang Z, Lohr L, Escalante C, Wetzstein M (2010) Food versus fuel: what do prices tell us? Energy Policy 38(1):445-51

Zheng Z, Henneberry SR (2012) Estimating the impacts of rising food prices on nutrient intake in urban China. China Econ Rev 23(4):1090-103

\section{Submit your manuscript to a SpringerOpen ${ }^{\circ}$ journal and benefit from:}

- Convenient online submission

- Rigorous peer review

- Immediate publication on acceptance

- Open access: articles freely available online

- High visibility within the field

Retaining the copyright to your article 